\title{
Reflections on Teaching and Learning in Southwest Associated University
}

\author{
Mi Fu*, Wude Cai \\ School of Physics and Electronic Information\&Technology, Yunnan Normal University, Kunming, China \\ Email address: \\ fumixin@126.com (Mi Fu),805737835@qq.com (Wude Cai) \\ ${ }^{*}$ Corresponding author

\section{To cite this article:} \\ Mi Fu, Wude Cai. Reflections on Teaching and Learning in Southwest Associated University. Education Journal. \\ Vol. 9, No. 6, 2020, pp. 158-162. doi: 10.11648/j.edu.20200906.12
}

Received: October 27, 2020; Accepted: November 9, 2020; Published: November 19, 2020

\begin{abstract}
As a miracle in the history of education in China and even in the world, Southwest Associated University has far-reaching influence on its spiritual connotation and educational model. Southwest Associated University has experienced the baptism of war, but it still cultivated many talents and masters for China. In the process of running a school in Southwest Associated University, the school has a clear purpose of running a school, a variety of teaching styles, a high degree of academic freedom, innovation and pragmatism. And students can combine work, study and research, learn from each other, and have an excellent learning atmosphere. Today's education in China needs to learn the spirit of Southwest Associated University, including education model, teaching style, free spirit and so on. Based on the exploration and thinking of "teaching and learning" of Southwest Associated University, this paper puts forward some opinions on the improvement of current education model and the inheritance of education concept. The three most important points are the unity of education and education, the inheritance of educational concepts, and the call for freedom. More importantly, we need to learn from Southwest Associated University to keep up with the social trend, to cultivate people who really need it and a long-term educational vision for the society. This paper hope that we can develop today's education by learning from the education of Southwest Associated University.
\end{abstract}

Keywords: Southwest Associated University, Teaching and Learning, Educational Model, Educational Concept

\section{Introduction}

The importance of education to a country is self-evident. In recent years, more and more voices have turned to education. The great reconstruction of the Chinese nation is from the revival of education. And a great signpost of educational revival is the "Southwest Associated University", whether it is the "teaching" of the Southwest Associated University or the "learning" of the Southwest Associated University, whether it is the "teacher" of the Southwest Associated University or the "student" of the Southwest Associated University. "Whether it is the "education model" of Southwest Associated University or the "educational concept" of Southwest Associated University, it has extraordinary significance for the development and revitalization of our current education.

\section{The "Teaching" of Southwest Associated University}

The Southwest Associated University was jointly established by Tsinghua University, Peking University, and Nankai University. It has 26 departments [1]. It can be regarded as a beacon for domestic education during the Anti-Japanese War. Many masters and scholars gathered in one roof, with different styles of teaching methods, and various teaching concepts collided at Southwest Associated University, sparking bright fireworks.

\subsection{Targeted}

Southwest Associated University upholds the education concept of "academic freedom and inclusiveness". The meaning of "freedom" and "inclusiveness" here is 
comprehensive, and what is reflected in education and teaching is "to cultivate good young people, we must first train good teachers ". It is the purpose of running a school in Southwest Associated University. This has played a purposeful guiding role for the "teaching" of Southwest Associated University, and has made the education and teaching work of Southwest Associated University have a clear goal. All education and teaching work is organized around this school purpose [2].

Under the tense and critical domestic environment, there is a shortage of talents in various fields and various fields [3]. The establishment of Southwest Associated University is to solve this urgent problem [4]. The leadership team of Southwest Associated University is also clearly aware of the long-term development perspective. The purpose of training excellent teachers is not only to solve the problem of domestic talent shortage, but also to solve the continuous supply of talents and prevent the problem of talent gaps. It is also due to the purpose of running a school with a clear goal that gives the teaching work of Southwest Associated University a "core". From the perspective of the long history of development, this school purpose has played an indelible and brilliant role in the cultivation of talents in China. And even become a highlight in the history of world education.

\subsection{Eclectic}

What is meant by "eclectic", that is, not limited to one style, one method, and one pattern. Southwest Associated University was jointly established by three universities. There are many masters and scholars. Different teachers in different schools have different educational concepts, teaching methods, and even teaching languages [5]. This difference in education and teaching methods emanating from the diversity and diversification of the teacher group makes the "eclectic" teaching connotation more vivid and fascinating.

Diversified teaching methods are able to attract different students' interest and suit different students' learning styles. Southwest Associated University has research scholars who draw on the strengths of the West, as well as famous masters who promote the classics of ancient Confucianism. There are also schools of ideas that integrate Chinese and Western styles. They are open, conservative, classical, popular, cultural, and skilled. These masters have their own cultural beliefs and teaching backgrounds. Because of their family and country feelings gathered at Southwest Associated University, the eclectic education and teaching methods continue to innovate and influence young students. It is precisely the inheritance and development of this "eclectic" spirit that has blossomed into the later Chinese education and a hundred schools of thought are contending.

\subsection{Innovative and Pragmatic}

The teaching of Southwest Associated University is closely aligned with the social reality at the time. While ensuring that teaching meets the needs of society, it actively innovates teaching methods and promotes educational development.
Take the Department of Aeronautical Engineering of Southwest Associated University as an example. Its original intention was to adapt to the tense war situation at that time and cultivate outstanding aviation professionals. In addition to studying advanced aviation technology and theories from abroad (the main object of study was the Massachusetts Institute of Technology at the time), also researching aviation technology on its own, which has greatly promoted the development of the domestic aviation field [6]. There is also a teacher promotion class launched by Southwest Associated University [7]. In order to cope with the current situation, it has adopted the shortened school system, lectures during holidays, and flexible graduation. It has created a new education and training model and has also cultivated a large number of new educational concepts and teachers of teaching methods.

Innovation and pragmatism are the two major advantages of Southwest Associated University's education and teaching. How to limit and evaluate innovation and pragmatism cannot be generalized. How to implement innovation and pragmatism is also a major problem to be solved in today's education. It requires both a down-to-earth and starry sky.

\section{3. "Learning" of Southwest Associated University}

The educational model of Southwest Associated University lies in its unique form of "teaching", and "learning" as another subject also has its profound significance. The benign interaction between "teaching" and "learning" has shaped the education model that Southwest United University has influenced so far.

\subsection{Integration of Work, Study and Research}

Under the historical conditions at that time, "going to school" was an extremely difficult task, even facing the danger of being bombed by Japanese planes at any time and losing their lives. This is a huge challenge for teachers and scholars as well as for ordinary students [8]. Working, studying and researching is a true portrayal of the state of study of Southwest Associated University students at that time. Although the Education Bureau and all walks of life provided great funding to Southwest Associated University at that time, to a certain extent, it was still very difficult, especially for students, the tremendous physical and psychological pressure they were under was unimaginable [9]. The school held many engineering-study collaboration activities, including factory internships, highway surveying and mapping, and appliance manufacturing. On the one hand, it exercised students hands-on ability, combined theory with practice, and on the other hand eased the financial burden of students. In addition to participating in school-enterprise cooperation, students also pay attention to the improvement of their own research capabilities, and jointly participate in the research of professors and scholars, focusing on the improvement of analytical capabilities and comprehensive capabilities. This 
three-in-one learning method of "work", "study" and "research" is undoubtedly It is a paradigm of contemporary education and teaching.

The trinity learning model of work, study and research is very enlightening. What needs to be pointed out is that only practical engineering research can really play its role. The "engineering research" of Southwest Associated University is not a top-down copying, but a bottom-up divergence, not just sticking to engineering research, but It is a kind of divergence in the spirit of perseverance and fortitude. It also incorporates a patriotic sentiment. It actively participates in national salvation fund-raising, organizes patriotic lectures and publicity, and further builds the connotation of "learning" in Southwest Associated University.

\subsection{Mutual Learning and Reference}

Mutual learning is not only limited to the mutual learning and reference between students, but also the mutual learning of different schools and teachers, and the spreading learning atmosphere has nurtured the students of Southwest Associated University. For example, Mr. WEN Yi-duo's class, during the teaching of Zhuangzi's thought, includes the comparison of ancient and modern Chinese and foreign thoughts, the transformation and development of social systems, and the significance of the impact on modern and contemporary. This is a typical "mutual learning and mutual learning". Moreover, the students in the room were bustling with each other, including the majors and non-majors, and even the classroom aisles were not crowded [10].

The fine atmosphere of mutual learning and reference has nourished the students of Southwest Associated University, and the ultimate meaning of mutual learning and reference is reflected in the word "freedom". Mutual learning and reference is not simply plagiarism or total resistance, but the ability to learn from one's strengths and learn the best. During the running of Southwest United University, no student was punished for plagiarism. The influence of this kind of education is double-sided, and it is the result of the combined effect of "teaching" and "learning" at Southwest Associated University.

\subsection{Education Style}

The style of education is a problem that people consistently test. The textual research on the influence of the environment on learning has existed in ancient times, such as "The white sand is in the Nirvana, and it is dark with it." It is enough to explain the impact of the environment on the learning of students, and the style of study is precisely the environment. The embodiment of a factor. The American scholar, Mr. Fairbank, once lamented the style of study of Southwest Associated University, to the effect that in such a arduous living condition, there are still a group of teachers teaching and a group of students learning, which is incredible. It was in the harsh environment of the Anti-Japanese War that the students of Southwest Associated University became more diligent and encouraged, in addition, "You can read and study in tea-houses and courtyards."

Actually, it is difficult for us to imagine the state of learning and psychological activities of students at that time. However, the prevalence and far-reaching influence of this learning atmosphere is by no means confined to campuses and the group of teachers and students. It has also had a positive impact on other regions and schools in Yunnan, and even set off a learning trend in Yunnan [11]. So far, we can still get a glimpse of the learning atmosphere in Yunnan universities, which also arouses our introspection and thinking about the frivolity of education and learning style.

\section{Thinking and Enlightenment}

Nowadays, China's development must be built for education. People's eyes are focused more on the Southwest United University that has created countless glories. The importance of education in a country is self-evident. Under the current complex international forms and changing demand for talents, Southwest Associated University has left us with many thoughts and inspirations.

\subsection{Integration of Communication and Expertise}

The education model of Southwest Associated University is biased towards generalist education. This education model was contacted and studied by Tsinghua University President MEI Yi-qi during his stay in the United States. After returning to China, he vigorously praised this education model at Tsinghua University and later Southwest Associated University. This kind of "generalist education" thinking was in line with the historical practice of that time. Under the unique education and teaching background of Southwest Associated University, to gain the strengths of hundreds of families and cultivate talents needed by the current social situation, this is also the training model of generalist education that echoes the president of MEI Yi-qi. This education model can provide students with comprehensive knowledge learning and comprehensive ability training. It is similar to the current concept of cultivating talents with all-round development in morality, intelligence, physical education, art and labor. More importantly, the training model of general education meet the requirements of the times and society [12].

The current education model is still the training model of generalist education, but the "generalist" here does not fit well with the requirements of society and the times for talents. The current university training model seems to be extensive, learning China and abroad, learning from the past to the present, but in practical applications, it makes students feel at a loss. They only have a taste of knowledge and professional learning. They seem to be generalists who know everything, but in fact they are nothing. This is a misunderstanding of generalist education. The "generalist education" mentioned by the author here is more like a reminder to re-understand the education model of generalist education proposed by President MEI Yi-qi. As we all know, in the context of new engineering and new liberal arts, there are new requirements for the training of school talents. It not only requires training 
in general education courses and quality education, but also requires cultivating people and minds, and cultivating students' majors, so that students can become compound professionals required by society, rather than students who feel that everything can be really nothing.

"Integration of communication and expertise" is not a new education model, but a reminder to review the talent education model of Southwest Associated University and not to generalize with "university". Does society need generalists? The answer is no, but why the society does not recognize the talents cultivated by schools? This is the question that should cause us to think. Keeping up with the needs of society and the times, appropriately adjust the education model, and cultivate compound talents who "integrate general education and professionalism" in the new era.

\subsection{Concept Inheritance}

The concept referred to here mainly refers to the spirit of struggle, the style of education and patriotism. According to Maslow's hierarchy of needs theory [13], needs always develop from low-level to high-level. However, the teachers and students of Southwest Associated University, when the problems of life safety and food and clothing are difficult to solve. The energy, perseverance, and self-improvement spirit of striving is awe-inspiring. The spirit of striving cannot be forgotten at any time. It is precisely because we live in today with abundant educational resources and abundant material conditions, we must remember our hardships and spirit of struggle.

The inheritance of the style of education of the educational philosophy requires a clear understanding that the style of education is conducted in both directions. A group of teachers and students who love to learn can change the learning atmosphere in one place, and a good learning atmosphere in one place can also affect a group of teachers and students in learning. And cultivating a culture of education is not only the behavior of the school, but also the social level, the family level, and the students themselves. We yearn for the strong academic atmosphere and learning environment of Southwest Associated University, which is the result of the concerted efforts of several parties [14]. The inheritance of the educational philosophy rests on each of us, which means that everyone can learn the theoretical knowledge of education, not only the students of the teacher majors need to learn, but also promote the need for the whole nation to learn the theoretical knowledge of education and teaching, and Practice by yourselves and lead by example. The inheritance of the style of education is not a matter of one person or several people, but a matter of cooperation among society, schools, families, and individuals.

There is also the most important point in the inheritance of idea: "patriotism". The reason why Southwest Associated University can be established, can bring together so many teachers and students, can cultivate countless outstanding talents, the root of which is inseparable from the four words of "patriotism"[15]. The hardships and hardships they endured unimaginable to us, and the things that supported them to move forward, must be derived from their inner patriotism.
The so-called "Morality Education"-seeing virtue in the subtleties, and subconsciously fostering people, so Southwest Associated University can cultivate a batch of founding talents, and it can become an institution that we still want to reshape its glory! This is also the fundamental reason why we continue to trace the roots and continue to pass on their ideas.

\subsection{Free Spirit}

For the definition of "freedom" in Southwest Associated University, it is difficult for us to give an exact definition and proper evaluation [16]. The same is true for "freedom" in the current education circle. What is freedom? Academic freedom, freedom of communication, freedom of thought? What is freedom? Free teaching methods, free educational models, free educational concepts? The spirit of freedom cannot be generalized. The spirit of freedom in Southwest Associated University is not a kind of rigid freedom, it is not that it does not manage any aspect, let it develop, nor is it restricted to its development, in this "living" spirit of freedom, orderly get on. The freedom of Southwest Associated University is that the teachers and students of Southwest Associated University clearly know what they are doing, what they want to do, and what they should do. This is a highly self-disciplined freedom. They can both restrain themselves and let their own thoughts go. Traveling in the sky, this is the true spirit of freedom of Southwest Associated University, and it is what we should learn from now.

\section{Concluding}

Southwest Associated University can be regarded as a landmark university in the history of Chinese education. Its teaching and learning, educational model, and educational concept still have important reference significance for today's education, and it is worthy of our reflection and study. The size of Southwest Associated University does not lie in how big it is, but in essence. That is why "the mountains will stand up and the scenery will stop, even though they can't reach, the heart yearns for it."

\section{References}

[1] Yu Z. X. (2001). Educational response under the national crisis. Wuhan: Central China Normal University Press, pp. 186-189.

[2] The Yunnan Provincial Department of Education and the National Southwest Associated University jointly established the Measures for the Promotion of In-service Teachers in Secondary Schools in Yunnan Province (1998). Peking University, Tsinghua University, Nankai University, Yunnan Normal University. Historical Materials of the National Southwest Associated University: Overview Volume. Kunming: Yunnan Education Press, pp. 4-9.

[3] Yu Z. X., Ran C. (2008). The history of the development of education in the western part of China in modern times-focusing on the period of the Anti-Japanese War. Beijing: People's Education Press, pp. 313-315. 
[4] Zhang M. C. (2020). The Local Education Services of Teachers College of National Southwest Associated University. Journal of Beijing Institute of Education, (2): 83-92.

[5] Zhang S. Y. (2013). My Southwest Associated University-ZHANG Shi-ying's Fragmentary Memory. Academic Monthly, (2): 167-168.

[6] Yunnan Provincial Archives (2016). The Southwest Associated University in the archives. Kunming: Yunnan Nationalities Publishing House, pp. 24-25.

[7] Normal College Regulations (1938). The Bulletin of the Ministry of Education, (8): 31.

[8] Zhao F. (1940). Student life in Southwest Associated University. Siyou Monthly, (8): 27-29.

[9] Han S. F. (2016). Southwest Associated University. Beijing: China Literature and History Publishing House, p. 162.

[10] Zi H. (1945). Special Issue on Democratic Education: The Southwest Associated University with Free Teaching. Wartime Education, (2): 25-26.
[11] Kunming Southwest Associated University Alumni Association (1945). What is the spirit of the United Nations University. Time Review (Kunming), (7): 2.

[12] Tian Z. P. (2016). Some Thoughts on the Education of the Republic of China. Journal of Education, (04): 102-111.

[13] Ye H. S. (1998). The history and system of western psychology. Beijing: People's Education Publishing, pp. 564-565.

[14] Wen Z. (1941). Today's Southwest Associated University. Universal Wind, (112): 76-81.

[15] Jia G. (2020). The Development of Higher Engineering Education During the Anti-Japanese War: A Case Study of Southwest United University. Education Teaching Forum, (33): 16-18.

[16] He Z. W. (2006). Going to School. Beijing: Sanlian Bookstore, pp. 109-110. 